\title{
INTERVAL TRAINING IS INSUFFICIENT TO ATTENUATE METABOLIC DISTURBANCES IN DIABETIC RATS
}

\author{
TREINAMENTO INTERVALADOÉINSUFICIENTE PARA ATENUARDISTÚRBIOS METABÓLICOS \\ EM RATOS DIABÉTICOS
}

\begin{abstract}
ENTRENAMIENTO A INTERVALOS ES INSUFICIENTEPARA ATENUAR TRASTORNOS METABÓLICOS EN RATAS DIABÉTICAS
\end{abstract}

\author{
Ricelli Endrigo Ruppel da Rocha \\ (Educador Físico) \\ Everson Araújo Nunes² \\ (Nutricionista) \\ Graciela Delia Venera ${ }^{3}$ \\ (Farmacêutica) \\ Luiz Claudio Fernandes ${ }^{4}$ (Biólogo) \\ 1. Universidade Federal do Paraná \\ (UFPR), Campus Curitiba, SC, Brasil; \\ 2. Universidade Federal de Santa \\ Catarina (UFSC), Florianópolis, \\ SC, Brasil; \\ 3. Instituto Universitário Italiano de \\ Rosário (IUNIR), Rosário, \\ Santa Fé, Argentina. \\ 4. Universidade Federal do Paraná \\ (UFPR), Campus Curitiba, PR, Brasil.
}

\section{Correspondência:}

Rua: Visconde de Mauá, 77, ap. 105, Centro, Caçador, SC. Brasil. 89500-000

ricelliendrigo@yahoo.com.br

\begin{abstract}
Introduction: Type 1 diabetes is a metabolic disease associated to blood disturbances and disorder of the innate immune system functionality. Objective: This study investigated the effect of two weeks interval training on blood biochemistry and immunological parameters in rats with type 1 diabetes. Methods: Male Wistar rats were divided into three groups: sedentary ( $S E, n=10)$, diabetic sedentary $(D I, n=10)$, diabetic interval training (DIT, $n=10)$. IV injection of streptozotocin ( $45 \mathrm{mg} / \mathrm{kg}$ ) induced diabetes. Interval training consisted of swimming exercise for 30 seconds with 30 seconds of rest for 30 minutes three times a week during two weeks, with an overload of $15 \%$ of the total body mass. The evaluations performed were fasting blood glucose, triglycerides, very low-density lipoprotein cholesterol, low-density lipoprotein cholesterol, high-density lipoprotein cholesterol and total cholesterol concentrations, phagocytic capacity, cationic vesicles content, superoxide anion, and production of hydrogen peroxide of blood neutrophils and peritoneal macrophages. Results: The results showed that two weeks interval training did not attenuate the hyperglycemic state at rest and did not decrease blood lipids in the DIT group. Diabetes increased the functionality of blood neutrophils and peritoneal macrophages in the DI group. Interval training increased the content of cationic vesicles and the phagocytic capacity of blood neutrophils and peritoneal macrophages in the DIT group. Conclusion: It was found that two weeks of interval training increased the functionality parameters of innate immune cells, although this has been insufficient to attenuate the biochemical disorders caused by diabetes.
\end{abstract}

Keywords: diabetes mellitus; immune system; hyperglycemia.

\section{RESUMO}

Introdução: O diabetes tipo 1 é uma doença metabólica associada a alterações sanguíneas e distúrbios da funcionalidade do sistema imunológico inato. Objetivo: Este estudo investigou os efeitos de duas semanas de treinamento intervalado sobre a bioquímica sanguínea e os parâmetros imunológicos em ratos com diabetes tipo 1. Métodos: Ratos Wistar machos foram divididos em três grupos: sedentário (SE, $n=10$ ), sedentário diabético $(S D, n=10)$, treinado diabético (TD, $n=10)$. O diabetes foi induzido por uma injeção IV de estreptozotocina $(45 \mathrm{mg} / \mathrm{kg})$. O treinamento intervalado de natação consistiu em 30 segundos de exercício, com 30 segundos de recuperação, por 30 min., três vezes por semana, durante duas semanas, com sobrecarga de 15\% da massa corporal total. Foram avaliados: glicemia de jejum, triglicerídeos, frações de lipoproteínas de muito baixa densidade, baixa densidade e alta densidade do colesterol, concentrações do colesterol total, capacidade fagocítica, conteúdo de vesículas catiônicas, produção de ânion superóxido e produção de peróxido de hidrogênio pelos neutrófilos sanguíneos e macrófagos peritoneais. Resultados: Os resultados mostraram que duas semanas de treinamento intervalado não atenuaram o estado hiperglicêmico em repouso e não diminuíram os lipídeos sanguíneos do grupo TD. O diabetes aumentou a funcionalidade dos neutrófilos sanguíneos e dos macrófagos peritoneais no grupo SD. O treinamento intervalado aumentou o conteúdo das vesículas catiônicas ea capacidadefagocítica dos neutrófilos sanguíneos e macrófagos peritoneais no grupo TD. Conclusão: Em duas semanas de treinamento intervalado verificou-se aumento dos parâmetros de funcionalidade das células do sistema imunológico inato, que foi, porém, insuficiente para atenuar os distúrbios bioquímicos causados pelo diabetes.

Descritores: diabetes mellitus; sistema imunológico; hiperglicemia.

\section{RESUMEN}

Introducción: La diabetes Tipo 1 es un trastorno metabólico asociado con alteraciones de la sangre y trastornos de la funcionalidad del sistema inmunológico innato. Objetivo: Este estudio investigó los efectos de dos semanas de entrenamiento a intervalos sobre la bioquímica de la sangre y los parámetros inmunológicos en ratas con diabetes tipo 1. Métodos: Ratas Wistar machos fueron divididos en tres grupos: sedentario ( $S E, n=10)$, sedentario diabético $(S D, n=10)$, entrenado diabético ( $E D, n=10)$. La diabetes se indujo por medio de inyección IV de estreptozotocina (45 mg/kg). El entrenamiento a intervalos consistió en ejercicios de natación de 30 seg. con 30 seg. de recuperación por 30 minutos, tres veces por semana durante dos semanas, con una sobrecarga del 15\% de la masa corporal total. Se evaluaron: glucemia en ayunas, triglicéridos, las fracciones de lipoproteínas de muy baja densidad, de lipoproteínas de baja densidad, de lipoproteínas de alta densidad del colesterol, las concentraciones de colesterol total, la capacidad fagocítica, contenido 
catiónico vesicular, producción de anión superóxido, producción de peróxido de hidrógeno por neutrófilos sanguíneos, y macrófagos peritoneales. Resultados: Los resultados mostraron que dos semanas de entrenamiento a intervalos no atenuó el estado hiperglucémico en reposo ni disminuyó los lipidos sanguíneos en el grupo ED. La diabetes aumentó la funcionalidad de los neutrófilos sanguíneos y de los macrófagos peritoneales en el grupo SD. Elentrenamiento a intervalos aumentó el contenido de las vesículas catiónicas y la capacidad fagocítica de los neutrófilos de la sangrey los macrófagos peritoneales en el grupo ED. Conclusión: En dos semanas de entrenamiento a intervalos se verificó el aumento de los parámetros de funcionalidad de las células del sistema inmunológico innato, que sin embargo fue insuficiente para atenuar los trastornos bioquímicos causados por la diabetes.

Descriptores: diabetes mellitus; sistema inmunológico; hiperglucemia.

\section{INTRODUCTION}

Type 1 diabetes (T1D) is a chronic autoimmune disease characterized by the loss of insulin producing cells in the pancreas and affects $10 \%$ of the population in the developed world ${ }^{1}$. This metabolic disease is associated with hyperglycemia, which leads to many alterations lipids and lipoprotein metabolism, increasing risk of atherosclerosis and other cardiovascular diseases ${ }^{2}$. Nevertheless, T1D has been associated with various defects in the innate immune system, which in turn may increase the risk of infections ${ }^{3}$.

For type 1 diabetes, successful management of the disease is based on individualized insulin therapy, adjusted diet and regular exercise ${ }^{4}$. Regular exercise is associated with significant health benefits for patients with type 1 diabetes, including increased cardiorespiratory fitness, decreased insulin requirements, improved endothelial function, decreased serum cholesterol, and increased vascular health along with improvements in body composition and quality of life ${ }^{5}$. Clinical practice guidelines recommend 150 min of moderate (50-70\% of person's maximum heart rate) to vigorous ( $>70 \%$ of person's maximum heart rate) physical activity weekly for adults with $\mathrm{T}_{1} \mathrm{D}^{6}$. However, more than $60 \%$ of adults with T1D do not achieve recommended levels of physical activity?

In recent years, there has been renewed interest in the application of interval training (IT) for improving health. A bout of IT involves repeated vigorous-intensity efforts lasting from a few seconds up to several minutes, separated by short periods of rest or recovery ${ }^{8}$. There is no standardized number, length, or intensity of the intervals in a IT session, which makes inherently difficult comparisons between research studies. Nevertheless, there is accumulating evidence that a variety of IT protocols are highly effective at improving cardiorespiratory fitness, endothelial function, glycemic control, lipids profile, blood presure, muscle metabolic capacity, and insulin sensitivity ${ }^{9}$.

Many researchers have used the experimental model of DM by streptozotocin (STZ) to investigate metabolic and immunologic alterations of DM. These animals exhibit many changes similar to those seen in humans with DM, such as hyperglycemia and dyslipidemia ${ }^{10}$. Our group have previously shown that, after six weeks of IT, STZ-induced diabetic rats present a significant reduction of glycaemia ${ }^{11}$. However, it is not known if a lower exercise volume will reproduced such findings. Therefore, here we investigate the effect of two weeks of interval training, using low volume and high intensity exercise, on blood biochemical and immune parameters in diabetic rats. We hypothesize that this protocol could attenuate the metabolic and some immune disturbances caused by type 1 diabetes model.

\section{MATERIALS AND METHODS}

\section{Animals}

All procedures involving animals were approved by the Local Committee of Animal Welfare of Universidade Federal do Paraná and were carried out in accordance with the ethical principles established by the Experi- mental Brazilian Council (COBEA), protocol number 23075.075135/2008-34. Seven-days-old male Wistar rats were kept at constant temperature $\left(23 \pm 1^{\circ} \mathrm{C}\right)$, under a light/dark cycle $(12 / 12 \mathrm{~h})$ with free access to food and water. The animals were randomly divided into three groups: sedentary (SE, $n=10)$, diabetic sedentary $(D I, n=10)$, diabetic interval training (DIT, $n=10)$.

\section{Enzymes and reagents}

Buffer reagents were obtained from Vetec Química Fina Ltda (Rio de Janeiro, RJ, BRAZIL). Streptozotocin was purchased from Sigma Chemical Co (St Louis, MO, USA). Bioliquid line kits (Laborclin Laboratory Products Ltda, Pinhais, PR, Brazil) were used for the biochemical assays.

\section{Induction of diabetes}

An insulin deficiency state was induced by a single intravenous injection of freshly prepared $45 \mathrm{mg} / \mathrm{kg}$ of STZ, dissolved in citrate buffer ( $\mathrm{pH} 4.8$ ), under ether anesthesia. The SE group received an equivalent volume of buffer solution. Blood samples were obtained from the tail 48-h after STZ administration. Animals with fasting blood glucose over $150 \mathrm{mg} / \mathrm{dL}$ were considered in a diabetic state ${ }^{12}$.

\section{Interval training protocol}

The interval training protocol was based on the model proposed by Braga et al. ${ }^{13}$ with minor modifications. The training was carried out in a swimming pool apparatus with temperature maintained between 30 and $32^{\circ} \mathrm{C}$. The apparatus was composed by two tubes with a fenestrated inner tube which allowed keeping the animal into the water and removing it at the end of the set. Initially the animals performed 1 week of water adaptation (Monday, Wednesday and Friday), swimming 15 minutes continuously with an overload of $6 \%$ of their body mass fastened to them through a vest. The second week the DIT group performed 30-s exercise with 30-s rest during 2 weeks, three times a week, with an overload representing 15\% of their body mass. Training sections were performed on Mondays, Wednesday and Fridays; all trained rats get rest in the other days. The SE and DI groups were submitted to the same transportation procedures and kept in a shallow pool during the time dispended by the exercising groups. At the end of 2 weeks of training, rats from all groups were anesthetized and decapitated 72 -h after the last session of exercise in order to eliminate the acute effect of exercise on metabolism. Blood was collected to obtain plasma and cells by centrifugation. Resident peritoneal macrophages and blood polymorphonuclear cells were obtained for determination of phagocytic capacity, cationic vesicles content, superoxide anion and hydrogen peroxide production.

\section{Biochemical parameters}

Plasma glucose, triacylglycerol (TAG), very low density lipoprotein (VLDL), low density lipoprotein (LDL) cholesterol, high density lipoprotein (HDL) cholesterol and total cholesterol (TC) concentrations were 
measured through colorimetric enzymatic assays as described by Togni et al. ${ }^{14}, 72$-h after the last training section and at least $12 \mathrm{~h}$ fast. The results are expressed as $\mathrm{mg} / \mathrm{dL}$.

\section{Macrophage isolation}

Resident macrophages were obtained by intraperitoneal lavage with $10 \mathrm{~mL}$ of sterile phosphate buffered saline (PBS). Peritoneal cells were collected by centrifugation ( $290 \mathrm{~g}$ at $4^{\circ} \mathrm{C}$ for $5 \mathrm{~min}$ ), washed, and resuspended in PBS or RPMI medium and counted in a Neubauer chamber by optical microscopy using a trypan blue solution (1\%); the resulted of viability was 96\%. Peritoneal cells were characterized by flow cytometry; purity was about 50\%. Macrophages were further purified by incubating peritoneal cells in tissue culture plates for $2 \mathrm{~h}$ and washed three times with PBS to remove non-adherent cells $s^{15}$.

\section{Blood polymorphonuclear cells isolation}

Polymorphonuclear cells were isolated from the blood of rats. Blood $(10 \mathrm{~mL})$ was diluted with an equal volume of PBS at $\mathrm{pH} 7.4$ containing $100 \mathrm{mM} \mathrm{CaCl}_{2}-50 \mathrm{mM} \mathrm{MgCl}_{2}$ and carefully layered on $10 \mathrm{~mL}$ of a commercial gradient of Ficoll-Paque Plus (density $=1.077$ ). The tube was centrifuged at $1.200 \mathrm{~g}$ at $18^{\circ} \mathrm{C}$ for $30 \mathrm{~min}$. The supernatant, rich in mononuclear cells, was discarded. The pellet was submitted to hypotonic treatment with 10 $\mathrm{mL}$ of solution containing $150 \mathrm{mM} \mathrm{NH}_{4} \mathrm{Cl}, 10 \mathrm{mM} \mathrm{NaHCO}_{3}$, and $0.1 \mathrm{mM}$ EDTA to promote lysis of contaminating erythrocytes. The sample was homogenized and maintained for $10 \mathrm{~min}$ at $37^{\circ} \mathrm{C}$ to allow erythrocyte lysis and then centrifuged at $1.200 \mathrm{~g}$ at $4^{\circ} \mathrm{C}$ for $10 \mathrm{~min}$. Centrifugation was repeated twice. Polymorphonuclear cells were counted in a Neubauer chamber under optical microscope. The number of viable cells, always $>95 \%$ neutrophils, was determined by trypan blue exclusion ${ }^{16}$.

\section{Phagocytic capacity}

Aliquots of peritoneal macrophage or blood neutrophil suspension $(0.1 \mathrm{~mL})$ were added to the wells of a 96 -well flat-bottomed tissue culture plate $\left(10^{5}\right.$ cells/well) and left to adhere for $60 \mathrm{~min}$. The non-adherent cells were washed twice with PBS. Then $10 \mu$ of neutral-red stained zymosan (1 $\times 10^{8}$ particles $/ \mathrm{mL}$ ) were added to each well. After incubation for $30 \mathrm{~min}$, the cells were fixed with Baker's formol-calcium (4\% formaldehyde, 2\% sodium chloride, $1 \%$ calcium acetate) for $30 \mathrm{~min}$. Afterwards, the cells were washed two times and centrifuged at $450 \mathrm{~g}$ for $5 \mathrm{~min}$. The neutral-red stain was solubilized by adding $0.1 \mathrm{~mL}$ of acidified alcohol (10\% acetic acid, $40 \%$ ethanol in distilled water) to each well. After $30 \mathrm{~min}$, the absorbance of each well was read on a plate reader at $550 \mathrm{~nm}$. The results were expressed as percentage of control ${ }^{15}$.

\section{Cationic vesicles content}

The uptake of the cationic dye neutral red, which concentrates mostly in cell lysosomes, was used to assess the volume of the peritoneal macrophage or blood neutrophil lysosomal system. Peritoneal macrophage or blood neutrophil suspensions $(0.1 \mathrm{~mL})$ were added to the wells of a 96-well flat-bottomed tissue culture plate ( $10^{5}$ cells/well) and left to adhere for $60 \mathrm{~min}$. The non-adherent cells were washed twice with PBS. Twenty microliters of $3 \%$ neutral red in PBS were added to the adhered cells per well for $30 \mathrm{~min}$. The cells were then washed twice with PBS by centrifugation (450 g for $5 \mathrm{~min}$ ). Neutral red was solubilized by a $30 \mathrm{~min}$ incubation adding $0.1 \mathrm{ml}$ of $10 \%$ acetic acid plus $40 \%$ ethanol solution. The absorbance was read at $550 \mathrm{~nm}$ and the cationic vesicles content was expressed as percentage of control ${ }^{15}$.

\section{Hydrogen peroxide production}

Hydrogen peroxide production by peritoneal macrophage or blood neutrophil was measured as described by Pizatto et al. ${ }^{17}$. This assay is based on the horseradish peroxidase (HRPO)-dependent conversion of phenol red into a colored compound by $\mathrm{H}_{2} \mathrm{O}_{2}$. After the 60 min of adhesion procedure and non-adherent cells washing macrophages or neutrophils (final volume $0.1 \mathrm{~mL})$ were incubated in the presence of glucose $(5 \mathrm{mM})$, phenol red solution $(0.56 \mathrm{mM})$, and $\mathrm{HRPO}(8.5 \mathrm{U} / \mathrm{mL})$ in the dark for $1 \mathrm{~h}$ at $20^{\circ} \mathrm{C}$. After this period, absorbance was measured at $620 \mathrm{~nm}$ on a plate reader. The concentration of $\mathrm{H}_{2} \mathrm{O}_{2}$ was determined from a standard curve prepared in parallel. $\mathrm{H}_{2} \mathrm{O}_{2}$ production is expressed as percentage of control ${ }^{17}$.

\section{Superoxide anion production}

Superoxide anion production was estimated by the reduction of nitroblue tetrazolium (NBT) assay. Peritoneal macrophage or blood neutrophil suspensions $(0.1 \mathrm{~mL})$ were added to the wells of a 96 -well flat-bottomed tissue culture plate $\left(10^{5}\right.$ cells/well) and left to adhere for $60 \mathrm{~min}$. The non-adherent cells were washed twice with PBS. Peritoneal macrophages or blood neutrophils $(0.45 \mathrm{ml})$ suspended in PBS was incubated for $1 \mathrm{~h}$ at $37^{\circ} \mathrm{C}$ in the presence of $0.1 \%$ NBT. The reaction was stopped by adding $0.45 \mathrm{ml}$ of acetic acid. Then the mixture was centrifuged for $30 \mathrm{~s}$ at $2.500 \mathrm{~g}$. Reduction of NBT results in the formation of blue formazan which was detected spectrophotometrically at 560 $\mathrm{nm}^{17}$. The results are expressed as percentage of control.

\section{Statistical analysis}

The Shapiro-Wilk test was used to verify the data normality per group, and the Levene test was used to analyze the homogeneities between group variances. No parametric statistic was employed for biochemical and immune parameters. Changes in body mass during two experimental weeks (pre- vs. post-training) were analyzed using Mann-Whitney test. Statistical analysis was performed by Kruskal-Wallis test. Tukey Post hoc test was applied for multiple comparisons and the data were analyzed using the Graph Pad Prism software version 6.0. The results were presented as mean \pm SEM. A value for $p<0.05$ was taken to indicate statistical significance.

\section{RESULTS}

\section{Total body mass}

Body mass (Table 1) from SE group increased significantly after 2 weeks (35.4\%, p<0.001). On the other hand, DI and DIT groups did not modify significantly the body mass when compared to pre-to post-training ( $p>0.05)$. In the post-training the diabetic state and exercise caused attenuation of the gain of body mass from DI and DIT group when compared to SE group $(p<0.05)$ (Table 1).

\section{Blood biochemical parameters}

The diabetic group increased the fasting glycaemia by $84 \%$, decreased the serum high density lipoprotein (HDL-C) cholesterol levels by $64,5 \%$ and increased the triacylglycerol (TAG) by $13.8 \%$ when compared to SE group, respectively, $(p<0.05)$ (Table 2$)$. Diabetic condition did not modify low density lipoprotein cholesterol (LDL-C), very low density lipoprotein (VLDL-C) and total cholesterol (TC) when compared to sedentary rats ( $p>0.05$ ) (Table 2 ). The interval training protocol did not modify the blood biochemical parameters in the diabetic rats submitted to interval training (DIT) when compared to DI group ( $p<0.05)$ (Table 2).

\section{Parameters of polymorphonuclear cells and peritoneal macrophages}

Phagocytic capacity, cationic vesicles content, superoxide anion and hydrogen peroxide production by neutrophils were assayed in all experimental groups (Table 3). Diabetic condition increased the phagocytic capacity by $61.3 \%$ when compared with SE $(161.3 \pm 9.4 \%$ and 
$100.0 \pm 5.2 \%$, respectively, $\mathrm{p}<0.01$ ) (Table 3). After 2 weeks of interval training the phagocytic capacity of DIT group increased 2.7-fold when compared to SE group $(p<0.0001)$. Interestingly, in the diabetic rats submitted to the interval training (DIT), the phagocytic capacity was even higher (1.3-fold) when compared to the DI group ( $p<0.01$ ) (Table 3).

The diabetes induced a 1.9-fold increment in the cationic vesicles content compared to the SE group (100.0 $\pm 2.5 \%$ and $294.7 \pm 14.3 \%$, respectively, $\mathrm{p}<0.01$ ) (Table 3). The interval training protocol increased the cationic vesicles content by 3.5 -fold in the diabetic rats when compared with the sedentary rats $(p<0.0001)$. Furthermore, the cationic vesicles content from DIT group was $53.7 \%$ higher when compared with Dl group $(p<0.01)$ (Table 3$)$.

Diabetes increased by $69.8 \%$ the superoxide anion production of DI compared with SE group $(169.8 \pm 8.7 \%$ and $100.0 \pm 3.9 \%$, respectively, $\mathrm{p}<0.01)$. Interval training increased $69.4 \%$ the superoxide anion production of DIT compared with SE group $(p<0.01)$. Between DI and DIT groups there was no difference in the production of this reactive oxygen species ( $p>0.05$ ) (Table 3 ).

Diabetic condition did not alter the hydrogen peroxide production compared with SE group ( $p>0.01$ ). The interval training did not modify the hydrogen peroxide production in the DIT group compared with SE ( $p>0.05)$. There was no difference also between DI and DIT groups ( $p>0.05$ ) (Table 3).

Phagocytic capacity, cationic vesicles content, superoxide anion, hydrogen peroxide production by peritoneal macrophages are shown in Table 4. There was no difference in the phagocytosis from DI group when compared to SE group ( $p>0.05$ ). After 2 weeks of interval training, three times a week, the phagocytosis by peritoneal macrophages increased by $84.4 \%$ in the DIT group when compared with sedentary rats (SE) $(p<0.05)$. Furthermore, the phagocytosis by peritoneal macrophages from DIT group was $44 \%$ higher when compared to DI group $(p<0.05)$ (Table 4$)$.

Diabetic condition (DI) increased by $65 \%$ the cationic vesicles when compared with SE group $(p<0.05)$. When diabetic rats accomplished the interval training (DIT) the cationic vesicles content increased by 1.1-fold when compared to SE group $(p<0.05)$. The cationic vesicles content from diabetic rats submitted to interval training (DIT) was $41 \%$ higher when compared to DI group $(p<0.05)$ (Table 4)

The diabetes (DI) decreased the superoxide anion production by $35.1 \%$ when compared with SE group $(p<0.001)$. When diabetic rats accomplished the interval training (DIT) the superoxide anion production was decreased by $37.4 \%$ when compared to SE group $(p<0.001)$ and there was no difference between DI and DIT groups $(p<0.05)$ (Table 4).

Table 1. Body mass (g) pre- and post- training moments from sedentary (SE), diabetic (DI) and interval training diabetic (DIT) groups during two experimental weeks.

\begin{tabular}{|c|c|c|c|}
\hline & SE & DI & DIT \\
\hline Pre-training body mass (g) & $277.4 \pm 4.9$ & $287.5 \pm 13.5$ & $289.9 \pm 23.3$ \\
\hline Post-training body mass (g) & $375.6 \pm 12.5^{*}$ & $300.3 \pm 13.3^{\mathrm{a}}$ & $274.3 \pm 22.8^{\mathrm{a}}$ \\
\hline
\end{tabular}

Table 2. Serum glucose, high density lipoprotein cholesterol (HDL-C), low density lipoprotein cholesterol (LDL-C), triacylglycerol (TAG) and total cholesterol (TC) concentrations from sedentary (SE), sedentary diabetic (DI) and interval training diabetic (DIT) groups at the end of two weeks of training.

\begin{tabular}{|c|c|c|c|}
\hline & SE & DI & DIT \\
\hline Glucose $\left(\mathrm{mg} \cdot \mathrm{dL}^{-1}\right)$ & $87.2 \pm 4.9$ & $151.6 \pm 14.7^{\mathrm{a}}$ & $184.4 \pm 14.6$ \\
\hline $\mathrm{HDL}-\mathrm{C}\left(\mathrm{mg} \cdot \mathrm{dL}^{-1}\right)$ & $27.1 \pm 5.4$ & $17.5 \pm 1.5^{\mathrm{a}}$ & $17.7 \pm 1.5$ \\
\hline LDL-C (mg.dL $\left.{ }^{-1}\right)$ & $35.7 \pm 1.6$ & $42.9 \pm 5.1$ & $45.5 \pm 7.3$ \\
\hline $\mathrm{VLDL}-\mathrm{C}\left(\mathrm{mg}^{\mathrm{dL}} \mathrm{dL}^{-1}\right)$ & $27.7 \pm 1.8$ & $26.5 \pm 3.2$ & $26.5 \pm 3.2$ \\
\hline TAG $\left(\mathrm{mg} \cdot \mathrm{dL}^{-1}\right)$ & $116.5 \pm 8.4$ & $132.6 \pm 6.0^{\mathrm{a}}$ & $129.5 \pm 4.0$ \\
\hline TC $\left(m g . d L^{-1}\right)$ & $87.4 \pm 3.5$ & $87.7 \pm 5.3$ & $84.5 \pm 7.0$ \\
\hline
\end{tabular}

Hydrogen peroxide production increased by $6.9 \%$ when compared with SE group $(p<0.0002)$ after 4 weeks of interval training $(I T)$. The diabetes (DI) increased hydrogen peroxide production by $6.9 \%$ when compared with SE group ( $p<0.0002)$. The interval training did not alter the hydrogen peroxide production of DIT compared with DI group ( $p>0.05$ ) (Table 4).

\section{DISCUSSION}

Our main finding was that IT protocol applied in this study, 30-s exercise with 30-s rest, three times a week, during two weeks, increased the functionality of blood neutrophils and peritoneal macrophages parameters. Nevertheless, the exercise neither did attenuate resting hyperglycemic state nor decrease blood lipids in the group of diabetic rats submitted to interval training.

Our results in this STZ-induced diabetes model showed body mass loss, and the training protocol did not alter body mass reduction caused by the diabetic state (Table 1). It has been demonstrated that rats treated with STZ to induce type 1 DM possess a compromised ability for normal skeletal muscle growth and impaired body weight gain ${ }^{11,18}$. Corroborating such information, our group have previoulsy showed that after six or eight weeks of STZ-induced diabetes $(60 \mathrm{mg} / \mathrm{kg}$ ) resulted in significant less body mass compared with controls in rats ${ }^{11}$. Similar findingns were also achieved by others, where eight weeks of STZ-induced diabetes (120 $\mathrm{mg} / \mathrm{kg}$ ) resulted in significantly less body mass, less absolute muscle mass, and less epididymal fat mass compared with control rats ${ }^{19}$.

The IT accomplished during two weeks, did not modify the hyperglycemia in the diabetic rats submitted to interval training compared with the DI group (Table 2). Few studies have been reported alterations of hyperglycemia with the interval training in type 1 diabetcs. Our group carried out a study with diabetic rats that accomplished a program of Interval Training (30-s exercise with 30-s rest, for 30 minutes, during 6 weeks) and there was a decreased of hyperglycemia in the interval training diabetic group ${ }^{11}$. In other study with diabetic rats that accomplished treadmill running high-intensity exercise protocol, during six weeks, there was also a decrease of hyperglycemia in the trained diabetic group after six weeks of exercise $\mathrm{e}^{20}$. We infer that the divergence between our results and the previous reported studies maybe be mainly related to volume of training (two weeks, total of six sessions) applied in the present study. According to Gibala et al. ${ }^{9}$ high-intensity interval training is infinitely variable with the specific physiological adaptations induced by this form of training determined by

Table 3. Blood neutrophils phagocytic capacity, cationic vesicles content, superoxide anion and hydrogen peroxide production in sedentary rats (SE), sedentary diabetic (DI), interval training diabetic (DIT) rats.

\begin{tabular}{c|c|c|c}
\hline & SE & DI & DIT \\
\hline Phagocytic capacity (\%) & $100.0 \pm 5.2$ & $161.3 \pm 9.4^{\mathrm{a}}$ & $372.2 \pm 12.1^{\mathrm{ab}}$ \\
\hline Cationic vesicles content (\%) & $100.0 \pm 2.5$ & $294.7 \pm 14.3^{\mathrm{a}}$ & $453.1 \pm 10.9^{\mathrm{ab}}$ \\
\hline $\begin{array}{c}\text { Anion superoxide } \\
\text { production (\%) }\end{array}$ & $100.0 \pm 3.9$ & $169.8 \pm 8.7^{\mathrm{a}}$ & $169.4 \pm 14.6^{\mathrm{a}}$ \\
\hline $\begin{array}{c}\text { Hydrogen peroxide } \\
\text { production (\%) }\end{array}$ & $100.0 \pm 1.3$ & $98.6 \pm 4.4$ & $102.9 \pm 3.3$ \\
\hline
\end{tabular}

Data are expressed as mean \pm SEM. ${ }^{\mathrm{a} P}<0.01$ compared with SE group. ${ }^{\mathrm{b}}<0.0001$ compared with DI group.

Table 4. Peritoneal macrophages phagocytic capacity, cationic vesicles content, superoxide anion, hydrogen peroxide production and adhesion obtained from sedentary rats (SE), diabetic (DI) and interval training diabetic rats (DIT).

\begin{tabular}{|c|c|c|c|}
\hline & SE & DI & DIT \\
\hline Phagocytic capacity (\%) & $100.0 \pm 2.5$ & $127.9 \pm 1.4$ & $184.4 \pm 2.4^{\mathrm{ab}}$ \\
\hline Cationic vesicles content (\%) & $100.0 \pm 3.2$ & $154.4 \pm 1.5^{\mathrm{a}}$ & $218.5 \pm 3.8^{\mathrm{ab}}$ \\
\hline Anion superoxide production (\%) & $100.0 \pm 5.6$ & $64.9 \pm 11.0^{\mathrm{a}}$ & $62.6 \pm 7.1^{\mathrm{a}}$ \\
\hline $\begin{array}{c}\text { Hydrogen peroxide production } \\
(\%)\end{array}$ & $100.0 \pm 1.6$ & $106.9 \pm 1.2^{a}$ & $105.5 \pm 1.2$ \\
\hline
\end{tabular}


a myriad of factors including the precise nature of the exercise stimulus (i.e. the intensity, duration and number of intervals performed, as well as the duration and activity patterns during recovery).

Some studies have shown that two weeks of interval training might improve skeletal muscle fatty acid oxidation, what could increase the use of the blood lipids as energy substrate for the muscles ${ }^{21,22}$. However, the IT protocol applied in this study, 30-s exercise with 30-s rest, three times a week for two weeks, did not alter blood lipids from DIT group compared to DI (Table 2). According to Taskinen ${ }^{23}$, the hyperglycemia caused by insulin deficiency affects key enzymes and pathways in lipid metabolism. Therefore, the lack of change in blood lipids might be related to the absence of effect caused by the IT protocol in the fasting glycaemia. Other possibility is that the very low volume of training applied by us (two weeks, only six sessions of exercise) is not enough to cause any systemic alteration in the parameters assayed by us.

Poor glycemic control has been shown to be an important risk factor for infections in type 1 diabetics ${ }^{24,25}$. Several studies have shown impairment of neutrophil function, a disorder that contributes to the high incidence of infections in diabetes ${ }^{26}$. Interestingly, in our study, the functionality of neutrophils and peritoneal macrophages from the DI group increased significantly (Table 3). Among many possible factors responsible for the stimulation of functionality of neutrophils and peritoneal macrophages in diabetic rats, hyperglycemia seems to be the most important. It seems that the increased plasma glucose level may activate innate immune cells by increasing plasma advanced glycation end products (AGEs) ${ }^{27}$ and by influencing intracellular carbohydrate metabolism ${ }^{11}$.

Exercise can have both positive and negative effects on immune system. While moderate activity may enhance immune function over sedentary levels, excessive, prolonged and high-intensity exercise may impair immune function ${ }^{28}$. Some studies have shown that relatively short periods of intense training ( 1 to 3 weeks), may reduce the function of innate

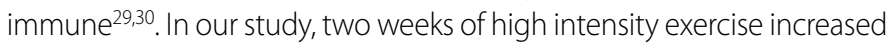
the phagocytic capacity and cationic vesicles content from neutrophils and macrophages in the training diabetics rats (Table 3-4)). These parameters showed that lysosomal capacity of immunotoxicity increased from neutrophils and macrophages, which in turn may reduce the risk of infections in the diabetic rats. Our group evaluated the effects of six weeks of interval training on functionality neutrophils and peritoneal macrophages of a STZ-induced diabetes model and also showed increased of functionality of immune cells in the trained diabetics rats ${ }^{11}$. Other important result of our study was that high intensity exercise, carried out for two weeks, did not negatively alter the function of innate immune cells.

\section{CONCLUSION}

In summary, our data show that STZ-induced diabetes model resulted in an increased functionality of blood neutrophils and peritoneal macrophages The low-volume high-intensity physical exercise further increased the innate immune cells' functionality. Nevertheless, two weeks of interval training was not sufficient to modify the biochemical disturbances caused by STZ-induced diabetes.

All authors have declared there is not any potential conflct of interests concerning this article.

CONTRIBUIÇÕES DOS AUTORES: Each author contributed individually and significantly to the development of the manuscript. RERR (0000-0002-4277-1407) * held interval training, biochemical analyzes, article writing, statistical analysis, intellectual concept and production of the entire research project. EAN (0000-0001-9994-5677) * collaborated in the writing of the article, statistical analysis and review. GDV (0000-0002-2053-3360) * conducted biochemical analyzes, drafting and revising it. LCF (00000001-9919-0681) * held the making of the design, drafting and revising it. *ORCID (Open Researcher and Contributor ID

\section{REFERENCES}

1. Lascar N, Kennedy A, Hancock B, Jenkins D, Andrews RC, Greenfield, S, et al. Attitudes and barriers to exercise in adults with type 1 diabetes (T1DM) and how best to address them: a qualitative study. PLoS ONE. 2014;9(9):e108019.

2. Safarzade A, Talebi-Garakani E. Short term resistance training enhanced plasma apoA-I and FABP4 levels in Streptozotocin-induced diabetic rats. J Diabetes Metab Disord. 2014;13:41.

3. Simonsen JR, Harjutsalo V, Järvinen A, Kirveskari J, Forsblom, C, Groop, PH, et al. Bacterial infections in patients with type 1 diabetes: a 14-year follow-up study. BMJ Open Diab Res Care. 2015;3(1):e000067.

4. Silverstein J, Klingensmith G, Copeland K, Plotnick L, Kaufman F, Laffel, L, et al. Care of children and adolescents with type 1 diabetes: a statement of the American Diabetes Association. Diabetes Care. 2005;28(1):186-212

5. Chimen M, Kennedy A, Nirantharakumar K, Pang TT, Andrews R, Narendran P. What are the health benefits of physical activity in type 1 diabetes mellitus? A literature review. Diabetologia. 2012;55(3):542-51.

6. Ryden L, Standl E, Bartnik M, Van den Berghe G, Betteridge J, de Boer MJ, et al. Guidelines on diabetes, pre-diabetes, and cardiovascular diseases: executive summary. The Task Force on Diabetes and Cardiovascular Diseases of the European Society of Cardiology (ESC) and of the European Association for the Study of Diabetes (EASD). Eur Hear J. 2007;28(1):88-96.

7. Yardley JE, Hay J, Abou-Setta AM, Marks SD, McGavock J. A systematic review and meta-analysis of exercise interventions in adults with type 1 diabetes. Diabetes Res Clin Pract. 2014;106(3):393-400

8. Little JP, Francois ME. High-intensity interval training for improving postprandial hyperglycemia. Res Q Exerc Sport. 2014;85(4):451-6.

9. Gibala MJ, Little JP, MacDonald MJ, Hawley JA. Physiological adaptations to low-volume, high-intensity interval training in health and disease. J Physiol. 2012;590(5):1077-84

10. De Souza CF, Machado AF, Bonatto SJR, Grando FCC, Pessini C, Alves LE, et al. Neutrophil response of anaerobic jump trained diabetic rats. Eur J Appl Physiol. 2008;104(6):1079-86.

11. Rocha RER, Coelho I, Pequito DC, Yamagushi A, Borghetti G, Yamazaki RK, et al. Interval training attenuates the metabolic disturbances in type 1 diabetes rat model. Arq Bras Endocrinol Metabol. 2013;57(8):594-602.

12. Yamazaki RK, Hirabara SM, Tchaikovski OJ, Lopes MCP, Nogata C, Aikawa J, et al. The effects of peroxovanadate and peroxovanadyl on glucose metabolism in vivo and identification of signal transduction proteins involved in the mechanism of action in isolated soleus muscle. Mol Cell Biochem. 2005;273(1-2):145-50.

13. Braga LR, Mello MAR, Gobatto CA. Exercício contínuo e intermitente: efeitos do treinamento e do destreinamento sobre a gordura corporal de ratos obesos. Arch Latinoam Nutr. 2004;54(1):58-65.

14. Togni V, Ota CC, Folador A, Junior OT, Aikawa J, Yamazaki RK, et al. Cancer cachexia and tumor growth reduction in Walker 256 tumor-bearing rats supplemented with $\omega 3$ polyunsaturated fatty acids for one generation. Nutr Cancer. 2003;46(1):52-8
15. Bonatto SJR, Folador A, Aikawa J, Yamazaki RK, Pizatto N, Oliveira HH, et al. Lifelong exposure to dietary fish oil alters macrophage responses in Walker 256 tumor-bearing rats. Cell Immunol. 2004;231(1-2):56-62.

16. Pithon-CuriTC, Schumacher RI, Freitas JJS, Lagranha C, Newsholme P, Palanch AC, et al. Glutamine delays spontaneous apoptosis in neutrophils. Am J Physiol Cell Physiol. 2003;284(6):C1355-61.

17. Pizatto N, Bonatto S, Piconcelli M, de Souza LM, Sassaki GL, Naliwaiko K, et al. Fish oil alters T-lymphocyte proliferation and macrophage responses in Walker 256 tumor-bearing rats. Nutrition. 2006;22(4):425-32.

18. Johnston AP, Campbell JE, Found JG, Riddell MC, Hawke TJ. Streptozotocin induces G2 arrest in skeletal muscle myoblasts and impairs muscle growth in vivo. Am J Physiol Cell Physiol. 2007;292(3):C1033-40.

19. Krause MP, Riddell MC, Gordon CS, Imam SA, Cafarelli E, Hawke TJ. Diabetic myopathy differs between Ins2Akita+/- and streptozotocin-induced type 1 diabetic models. J Appl Physiol. 2009;106(5):1650-9.

20. Kim JS, Lee YH, Kim JC, Ko YH, Yoon CS, Yi HK. Effect of exercise training of different intensities on anti-inflammatory reaction in streptozotocin-induced diabetic rats. Biol Sport. 2014;31(1):73-9.

21. Vincent G, Lamon S, Gant N, Vincent PJ, MacDonald JR, Markworth JF, et al. Changes in mitochondrial function and mitochondria associated protein expression in response to 2-weeks of high intensity interval training. Front Physiol. 2015;24(6):51.

22. Little JP, Gillen JB, Percival ME, Safdar A, Tarnopolsky MA, Punthakee Z, et al. Low-volume high-intensity interval training reduces hyperglycemia and increases muscle mitochondrial capacity in patients with type 2 diabetes. J Appl Physiol. 2011;111(6):1554-60.

23. Taskinen MR. Diabetic dyslipidemia. Atheroscler Suppl. 2002;3(1):47-51.

24. Thomsen RW, Riis AH, Kjeldsen S, Schønheyder HC. Impact of diabetes and poor glycaemic control on risk of bacteremia with haemolytic streptococci groups A, B, and G. J Infect. 2011;63(1):8-16.

25. Muller LM, Gorter KJ, Hak E, Goudzwaard WL, Schellevis FG, Hoepelman Al, et al. Increased risk of common infections in patients with type 1 and type 2 diabetes mellitus. Clin Infect Dis. 2005;41(3):281-8.

26. Alba-Loureiro TC, Hirabara SM, Mendonça JR, Curi R, Pithon-Curi TC. Diabetes causes marked changes in function and metabolism of rat neutrophils. J Endocrinol. 2006;188(2):295-303.

27. Tian M, Qing C, Niu Y, Dong J, Cao X, Song F, Ji X, Lu S. The relationship between inflammation and impaired wound healing in a diabetic rat burn model. J Burn Care Res. 2015;37(2):115-24.

28. Gleeson M. Immune function in sport and exercise. J Appl Physiol. 2007;103(2): 693-9.

29. Córdova A, Sureda A, Tur JA, Pons A. Immune response to exercise in elite sportsmen during the competitive season. J Physiol Biochem. 2010;66(1):1-6.

30. Woods JA, Lu Q, Ceddia MA, LowderT. Special feature for the Olympics: effects of exercise on the immune system: exercise-induced modulation of macrophage function. Immunol Cell Biol. 2000;78(5):545-53. 